\title{
Jim Crowther
}

\section{THE CONTRADICTIONS OF POPULISM: REASSERTING ADULT EDUCATION FOR DEMOCRACY}

\begin{abstract}
The context for this paper is the rise of populism across the UK, Europe and the US, a trend which is sweeping western liberal capitalist democracies in particular but also beyond in countries such as Turkey. Populism is used primarily as a derogatory label to demean the poor, working class groups and people with low educational attainment, as not having the experience or capacity to make wise decisions. In the UK this has led to demands for a second referendum on leaving Europe because the 'will of the people' was manipulated. It is also claimed that Parliament is sovereign so the decision to exit Europe should be made by its members who are better informed and can legitimately overturn the referendum decision. On the other hand, demagogues of the far right who led campaigns of disinformation and thinly veiled racist vocabulary to sway the Brexit result champion the 'will of the people' in disingenuous ways. If we widen our lens, there are also examples of progressive populist politics in Europe, such as Podemos in Spain, which are indicative of a counter-trend to the neoliberal model of globalization. Whilst populism is mainly used as a derogatory label, it can also be framed progressively as a response of the powerless, the poor and the ignored reacting to the limits of liberal democratic institutions in the current context. The election of Trump in the US and the Brexit result in the UK can be understood in these terms too. The repressed, overlooked or denigrated by the political and media elite, have responded at the only opportunity available to them. At the same time, the kind of social purpose adult education which aimed to engage with people in communities, on their own terms, has withered as neoliberal forms of lifelong learning and citizenship transform educational practices into 'remoralising' citizens to take care of themselves. In this context adult education and democracy are in crises. However, both crises can be turned towards generating productive synergies which adult educators need to connect with. This presentation seeks to explore and stimulate this debate.
\end{abstract}

Keywords: populism, interregnum, democracy, Scottish referendum

\section{PROTISLOVJE POPULIZMA: POTRJEVANJE VLOGE IZOBRAŽEVANJA ODRASLIH ZA DEMOKRACIJO - POVZETEK}

Članek je vpet v kontekst vzpona populizma v Zdrǔ̌enem kraljestvu, Evropi in ZDA, trendu, ki se še posebej širi $v$ zahodnih liberalnih kapitalističnih demokracijah, hkrati pa sega tudi drugam, na primer

Jim Crowther, PhD, University of Edinburgh, jim.crowther@ed.ac.uk 
v Turčijo. Izraz populizem je v rabi predvsem kot slabšalna oznaka z namenom poniževanja revnih delavskih skupnosti in ljudi z nizko stopnjo izobrazbe, ki naj ne bi imeli niti izkušenj niti sposobnosti za preudarno odločanje. V Združenem kraljestvu je to manipuliranje $z$ »judsko voljo « vodilo do zahteve po drugem referendumu o izstopu iz Evrope. Hkrati se pojavljajo trditve, da naj bi o izstopu odločali člani parlamenta, ki so bolj poučeni in lahko upravičeno ovržejo referendumsko odločitev. Po drugi strani pa demagogi skrajne desnice, ki so vodili kampanjo dezinformacij in prikrito rasističnega diskurza, da bi vplivali na rezultat brexita, varljivo podpirajo »ljudsko voljo«. Če pogledamo širše, opazimo tudi primere progresivne populistične politike v Evropi, na primer Podemos v Španiji, ki nakazujejo nasprotni trend neoliberalnemu modelu globalizacije. Populizem, sicer večinoma uporabljen kot slabšalna oznaka, $v$ progresivnem okviru označuje odziv nemočnih, revnih in prezrtih na omejenost liberalnodemokratičnih institucij $v$ sodobnem kontekstu. Izvolitev Trumpa in rezultat britanskega referenduma lahko razumemo tudi v tem smislu. Zatrti, spregledani ali očrnjeni s strani politične in medijske elite so se odzvali ob edini priložnosti, ki jim je bila na voljo. Tisti družbeni element izobraževanja odraslih, usmerjen k povezovanju z ljudmi v skupnostih, pod njihovimi pogoji, je zamrl, neoliberalne oblike vseživljenjskega učenja in državljanstva pa so preoblikovale izobraževalne prakse v »remoraliziranje«, da naj državljani skrbijo sami zase. V tem kontekstu sta tako izobraževanje odraslih kot demokracija v krizi. Vendar pa je obe krizi možno usmeriti k ustvarjanju produktivnih sinergij, čemur se morajo pridružiti izobraževalci odraslih. Namen tega prispevka je raziskati in spodbuditi to razpravo.

Ključne besede: populizem, interregnum, demokracija, škotski referendum

\section{INTRODUCTION}

The main purpose of this paper is to open up debate and dialogue rather than present a finished argument. In the UK both adult education and democracy are in crisis but, in some respects, both can be repaired by developing synergies between the two. Rather than framing the problem mainly as one of 'populism' and authoritarianism, perhaps the cracks occurring in liberal democracies present opportunities for widening and deepening democracy?

The crisis of liberal democracy is linked to the rise of neoliberal globalization which has undermined the power of nation-states to influence economic decisions by powerful transnational companies and international financial interests. The consequences in terms of political reactions, particularly from working class communities, has often been denigrated as populist, which is usually taken to mean bigoted, uneducated, racist and xenophobic. Whilst it is clear that there are problematic expressions of popular anger at 'the establishment' and the 'political elite', which can end in demands for a strong leader (e.g. Trump), it is also essential to recognize the legitimate democratic aspirations of people who have been victims of globalisation and ignored by liberal democracy. Indeed, working class communities have been at the sharp end of austerity policies and are still paying the price of the 2008 recession which started in the sub-prime housing market in the US but then spread outwards, having a global impact. Their political reactions to these events may be problematic, however, if adult education is to be a resource for developing 
political forces to deepen democracy, it needs to formulate a way of contributing to progressive social aspirations 'from below', rather than dismissing popular reactions as unwarranted and small-minded. I will draw on the work of Gramsci (1971), Laclau (2005) and Mouffe $(2016,2014)^{1}$ to develop this argument. At the same time, the kind of adult education which aimed to engage with people in communities, on their own terms, has withered as neoliberal forms of lifelong learning and citizenship transform educational practices into 'remoralising' citizens to take care of themselves. However, the crises of democracy and adult education can be turned towards generating productive synergies which adult educators need to develop. My argument is that reasserting adult education for democracy creates an opportunity to reinvigorate adult education and to reinvigorate democracy. This is supported by developments in the Scottish context.

\section{THE CRISIS OF ADULT EDUCATION}

The long-term erosion of adult education for democracy in Scotland is similar to the pattern in the rest of the UK where social purpose adult education has been systematically undermined by economistic versions of lifelong learning (Biesta, 2006).

Austerity measures have accelerated and magnified the trend of forcing cuts on public sector provision which has been central to neoliberal ideology since the 1980s onwards. In the alchemy of austerity, Clarke and Newman (2012) differentiate between the economic consequences of austerity which further inequality; political consequences which involve shifting the blame from structures and institutions to the moral lapses of individuals; social consequences which increase social divisions in communities; subjective consequences that change expectations and generate active consent. These multi-faceted consequences are relevant for thinking about the democratic impact of austerity on communities.

An increasing scarcity of resources makes it hard for small and struggling groups to sustain an organisational base and therefore maintain an independent voice. The result is that the active community shrinks or is redeployed into forms of consumer participation rather than active community development that involves communities defining their own interests and acting collectively to promote or defend them. As the state withdraws welfare provision, the community is co-opted into providing, for example, low-resourced service substitutes which they still need because of the closure of care homes, libraries and community centres, to be run by local volunteers on the cheap.

Austerity also sets community and voluntary groups in competition with each other in a scramble for scarce funding. One response is to 'play the game' by nominally working towards the outcomes which funders are willing to resource (e.g. often meaningless 'employability' projects), whilst at the same time stretching the meaning of policy, as far

1 I'm not claiming to be an authority on these two theorists and Laclau, in particular, seems to me very opaque in his writing. However, they both contribute to the analysis of populism as a potentially progressive social force - hence my interest in them. 
as practical, to do something different. Another response, however, has been a change in culture and subjectivities as groups and organisations seek to 'fit into' and embrace the dominant paradigm. The development of neoliberal subjectivities in the community sector, who work to the logic of market principles, marks a significant shift towards non-democratic and anti-democratic practices as the need for profitability replaces the significance of community engagement and control in decisions made.

Another powerful force moulding subjectivities consistent with the neoliberal project has been the dominant discourse of lifelong learning. Biesta (2006) makes a convincing argument about the impact of European Union, OECD and IMF discourses which reduce the focus of lifelong learning to narrowly economistic objectives, where social and economic 'problems' are supposedly amenable to learning 'solutions' i.e. 'learnification' in Biesta's awkward term. There may well be broader narratives of lifelong learning promoted by UNESCO through its Confintea conferences, but the overwhelming drive has been to see lifelong learning (to which adult education was tied) as a commodity to be purchased or as re-working the relationship between the individual and the state through the stripping away of the social rights of citizenship. Lifelong learning has come to mean learning 'for earning' rather than 'learning for yearning' (Martin, 2003). In the global 'north' it has generally developed as a disciplinary practice to prepare people for the labour market (Crowther, 2004) and to accept the imperatives of precarity as a mode for differentially evaluating some people who can work over others who cannot (Coffield, 1999). Its potential as a tool for social transformation from 'the bottom up' has been emasculated.

Neoliberalism in the public sector has also led to the growth of a culture of performativity through managerial practices imported from the business sector, such as performance target setting (Fraser, 2012). The focus on measuring what matters to policy, rather than what matters to people, reflects the incremental incorporation of adult education provision into the state's social, educational and economic policy objectives - particularly the latter. This diminution of purpose to vocational skills and 'employability', along with growing mandatory and coercive welfare rules to ensure people comply, have eroded the distinctiveness of adult education and morphed it into a pale shadow of its former self. Family literacy and parenting skills, which can be linked to promoting educational attainment in schools, is another example of how adult educators are deployed to serve performance outcomes set by Government. The main objective of educational intervention is to deliver communities to policy targets - not to engage with communities on their own terms - so that governments can claim successful interventions (Crowther, Martin and Shaw, 2007). However, education is not a pizza delivery service.

\section{THE CRISIS OF DEMOCRACY}

The bourgeois class is 'saturated': it not only does not expand, it starts to disintegrate; it not only does not assimilate new elements, it loses part of itself (or at least its losses are enormously more than its assimilations). (Gramsci, 1971, p. 276) 
The crisis of democracy is not only about the institutions of liberal democracy but also a crisis of the hegemonic claims of capitalism to provide the opportunity for never ending growth and social mobility which can absorb rising demands from working and middle-class groups. For the first time since the 1950s, young people cannot expect to have a better standard of living than their parents. In the context of neoliberal globalization, the widening of inequality between the rich and poor has accelerated the shift of power away from organized labour and reduced the power of nation-states to regulate the activities of the corporate and financial sectors. For example, companies such as Apple and Google negotiate with national governments the taxes they are willing to pay. It has also opened the door for scurrilous politicians and political factions to 'other' an 'enemy within', or to present social and economic problems as one of migrants and refugees seeking to take advantage of 'our' liberal values. Gramsci (1971) referred to the interregnum, a condition in which the old society is disintegrating and decaying but where the new society has not yet emerged, as a context full of 'morbid symptoms' but also, perhaps, of opportunities. Simply defending liberal democracy, which is part of this problem, ignores the need to transform democratic life. If adult education is to make a difference, then it also has to address the critical changes shaping liberal democratic institutions and the tensions between these changes, communities of the powerless, and global capitalism.

\section{Radicalising liberal democracy rather than abolishing it}

Liberal democracies are characterized by the rule of law, an independent judiciary, the protection of civil rights, civil liberties, political and press freedom, along with a system of checks and balances to limit any one branch of Government or Executive power acting unaccountably. Liberal democracies involve elected representatives, usually organized in political parties, which seek electoral support to enact their programmes in government. However, issues of accountability have to be addressed with proponents of direct democracy advocating for more participatory forms of engagement in decision-making. Of course, more participation in political thinking and decisions is laudable but so are the critical skills of holding powerful people to account. In any large, complex society, different degrees and forms of representation are inevitable, so it is essential that systems which involve the delegation of decision-making include democratic loops which enable people to hold their representatives to account. Another problem with liberal democracy is that, in the context of capitalism, the ideal of political equality is systematically undermined by massive economic inequalities which distort the system so that it undermines the liberal and egalitarian principles it claims to enshrine. In the UK it has also been characterized by political parties that differ on some policy areas but, primarily, see their main task as managing the economy rather than transforming it. The task, therefore, is to radicalize this system so that inequalities of power are counterbalanced by more democratic forms of control and influence. We need to therefore start with the recognition of political inequality. 


\section{Political inequality}

Political inequality exists where decision-making processes systematically benefit dominant social classes and groups who are able to use the system for their own ends (Lawrence, 2014). Such inequalities reinforce the need, as Nancy Fraser (2005) argues, for redistribution, recognition and representation to achieve social justice and make democracy meaningful. Maldistribution of economic power and low social status interact and undermine the possibility of successful representation of excluded voices. The experience of political inequality helps explain why democracy often falls far short of expectations for it. Political inequality shifts the argument away from thinking about the problem of democracy in terms of personal apathy and disinterest in politics, by relocating issues of motivation in structural inequalities in society, which systematically reproduce unequal political outcomes. In the UK the poor, working class communities, the least educated, young people and minority groups are all more likely to experience the disbenefits of political inequality (Lawrence, 2014).

\section{Post-Democracy}

Crouch (2004) refers to post-democracy in the sense that the historical tradition of the struggle for democracy has been undermined and reversed. As he puts it:

Democracy thrives when there are major opportunities for the mass of ordinary people actively to participate, through discussion and autonomous organization, in shaping the agenda of political life, and when these opportunities are being actively used by them (Crouch, 2004, p. 101).

The educative nature of democratic association is important to a thriving demos. Crouch, however, goes on to argue that contemporary experiences of democracy have seriously undermined this ideal. Politics and political debates become media spectacles which are tightly controlled; campaign strategists are experts in the powers of persuasion rather than generating critical engagement; the issues and agenda of politics reflect an implicit technocratic consensus; corporate interests are always dominant in the background; real power often lies outside political institutions in the sphere of multinational and transnational agencies, institutions and private companies; as a consequence, citizens are socialised into apathy and political disengagement.

\section{Populism}

In contrast to apathy and disengagement, however, there has been a dramatic and widespread surge of populist responses which have been evident in the UK Brexit referendum in 2016 and the Trump election in the US. Populism is often used pejoratively to attack the (unthinking) poor and badly educated by depicting them as easily influenced by powerful demagogues (Hindess, 2016). What this negative labelling does is undermine why political mavericks attacking the establishment, such as Donald Trump, have legitimate appeal to people; instead, the people making the choice are denigrated. 
Populism is not ideologically fixed and could, potentially, lead to progressive social and democratic outcomes. The experience of Podemos in Spain is an example of this (Mouffe, 2016). Populist reactions often reflect the failures of liberal democracy to address the inequities of capitalism and neoliberal globalisation with its 'winners' and 'losers'. Trump's 'America First' campaign connected with popular discontent over increasing inequality, widespread precarity and the failure of liberal democratic institutions to make a significant difference to poor people's lives. In the UK the message of Brexit was 'take back control' from EU institutions, which reflected a contradictory dissatisfaction with the centralisation of power and draconian policies of austerity, whilst also charming with a discourse of xenophobia and racism accompanying movements of refugees fleeing conflicts (White, 2017).

One contradiction of populism it is important to draw attention to is the discourse of renewing citizen agency in the figure of a powerful leader who will take on the establishment and repair the damage done by the liberal institutions that the privileged have used to their advantage. The analysis has traction whilst the solution of a powerful leader does not. To safeguard the interests of the working class and other marginalised communities from the predatory practices of neoliberal globalization, we need to do democracy better.

The rise of populism also seems to undermine the very foundation of radical education. If reason, evidence and argument are no longer important to political choices, what is the value of education? The issue of 'post-truth' politics is a case in point. Post-truth refers to overt attempts to mislead with inaccurate information; one counter-reaction is to offer the 'true facts'. The Trump election and the Brexit result suggest this type of response is unlikely to succeed. As the Canadian philosopher Ignatieff points out: "'Enlightenment humanism and rationalism' can no longer adequately 'explain the world we are living in", (cited in Mishra, 2016), and we therefore need to go beyond such narrow intellectual frameworks. The mere comparison of specious claims against factual realities misses the complex mix of reason and emotion that has to be addressed educationally.

If the crisis of democracy reflects the disconnect caused by the failure of politics and policies to listen to the voices and experiences of ordinary people, why should we be surprised at their cynicism, contempt and anger? Writing in the 1970s, Sennett and Cobb (1972) highlighted the hidden injuries of class as social conflicts in society are internalised into internal conflicts for the individual. This psychic damage people experience festers by being ignored, denied status, dignity and respect, whilst at the same time material inequality between social classes increases. The basis for trust between social groups breaks down when material inequalities are so great that people's lives share little in common. The result can be anger, malice and loathing towards the beneficiaries of the system but, unfortunately, also against minorities and others who are blamed in the media and by manipulative politicians seeking advantage from popular discontent by 'othering' some groups as the enemy within. But these negative outcomes are not inevitable. Anger can result in creative and critical agency for social change. 
Adult education can be a resource for turning such anger into hope, for fostering respect and belonging, and for turning despair into purposeful action (Martin, 2003).

Reason and emotion can change and interact in productive or destructive ways (Jasper, 1997). It would be very limiting to see them as mutually exclusive, or necessarily in conflict; the emotional impact of poverty and starvation, for example, can be a powerful motivator for rational action to address it. Reason and emotion are simply aspects of the human condition. The real problem is over-emphasising one at the expense of the other. Thus, educational engagement has to address the interplay between reason and emotion, that is, develop a critical pedagogy of the mind and the emotions, if it is to succeed in deepening and extending democratic life (see this argument in relation to climate change in McGregor and Crowther, 2016). Democracy is unfinished and education should be part of the process of exploring how it can become a resource for transforming society rather than merely managing its contradictions and tensions.

\section{WAYS OF DOING POLITICS: THE SCOTTISH EXPERIENCE}

A brief description of the 2014 referendum on independence: The Scottish referendum involved a yes/no decision on independence from the UK which was reflected in two campaign groups supported by different political parties. On the one hand, there were the mainstream political parties (the Conservatives, the Scottish Labour Party and the Liberal Democrats), who supported the politics of the union with the UK; on the other, two political parties (the Scottish National Party and the Green Party) which supported independence from the UK.

What was unexpected and, in some respects, had deeper consequences was the emergence of a range of unofficial campaign groups and spontaneous popular interest in the referendum issue. Community groups, organisations and movements across the length and breadth of the country were intent on propaganda and educational activities aimed at promoting or rejecting the cause of independence. Unofficial campaigns were active in 'real' spaces as well as in the digital sphere with over 700 blog sites and social media groups providing a vibrant, humorous, critical, opinionated and flourishing online opportunity for people to engage in politics in their own way, outside the restrictions of the mass media, formal political structures, parties and processes (for example, http://bellacaledonia.org.uk). People engaged, individually or collectively, through the activities of campaign groups, social media sites, friendship networks, online and offline, and locally-organised community provision, in discussion and debate about the issues that mattered to them. It was at the community level that a wide range of grassroots initiatives canvassed for voter registration, raised awareness, engaged in debate and in the main promoted independence. There were pro-union groups but these were much less visible and less active at a community level.

All this official and unofficial 'political education' had an impact on political thinking. Around $95 \%$ of the electorate registered to vote and over $85 \%$ voted on the day. People also learned to change their views. In 2013 support for independence was around 25\% 
but this increased significantly to almost $45 \%$ at the time of the vote in September 2014 (Curtice, 2014).

Analysis of the campaign as populist politics: According to Laclau (2005), what defines populism is a way of 'doing politics' which can take different forms but involves constructing the political by establishing a political frontier that divides society into two camps, appealing to the mobilization of 'the underdog' against 'those in power'. How the 'people' are constructed is critical to the nature of the conflicts generated and the ideological possibilities for change. When cracks appear in the dominant consensus of politics, these are opportunities to create linkages between different groups, through a populist identity, that can lead to alliances and the mobilization of change efforts. Laclau (2005) uses the term 'floating signifier' which refers to ambiguous ideas which can 'house' different claims and realign them. What is interesting about the Scottish experience is that the referendum on independence reflected the mobilization of conventional political subjects (i.e. voters in the classical sense of liberal democracy who were to choose a political preference) along with new political subjects who were self-organised and began to 'fill' the 'floating signifier' of independence with new political demands. This is outlined below in terms of two distinct political frontiers being established (which overlapped in reality).

1. Nationalism as a political frontier: there were two forms of nationalism which aimed to mobilise support for the unionist case and the case for independence. The case for independence was presented as a form of civic nationalism which was open to migrants and people who wanted to live and commit to Scotland. Independence was essential to achieve the level of political agency in Scotland that was being held back by the UK Parliament. On the fringes of this was also a form of identity nationalism, of being Scots first and foremost, and on the extreme edge of identity politics was a darker anti-English nationalism. The other nationalism on offer, although never represented in nationalist terms, was British nationalism. From this perspective, Scottish separatism would undermine the role of the UK in the wider world which had benefited from it. The British nationalist case was partly based on identity (with some extreme Union Jack flag waving supporters) but also on the benefits of the union to Scots - the benefits which derived from empire - as well as the social union and trade relations between England and Scotland which might be threatened by independence. The latter was raised in terms of the need to establish a border (build a wall in some accounts) between England and Scotland if independence happened.

2. Inequality and marginalization as the political frontier: overlapping the Scottish nationalist independence campaign was another, more radical form of populist politics, focused on the poorer areas of Scotland or less powerful communities, which argued for independence as a struggle to address inequalities of wealth and power linked primarily to social class, gender, 'race' and sexuality. The ideological content was disseminated in community-based campaign groups such as the Radical Independence Campaign ${ }^{2}$,

2 https://radical.scot 
Women for Independence ${ }^{3}$, the Women's Equality Party ${ }^{4}$, Scots Asians for Yes ${ }^{5}$, LGBTi for Independence ${ }^{6}$, Commonweal ${ }^{7}$ and so on. What these various groups shared was the need to fundamentally change politics by ensuring different voices, experiences and interests would be part of what independence would involve. The frontier was between the powerful and powerless, not simply British nationalism or Scottish nationalism, which deepening democracy could resolve.

What these different constructions of 'the people' represent are very different ways of doing politics, which are populist, bringing together new political subjects in some cases, but also based on a spectrum of ideological perspectives on the need for consensus or change to the status quo. What this paper will now focus on is the potential of these constructions, particularly the second - because of its recognition of the key issue of political inequality - to link learning and radicalizing democracy as a context for adult education.

\section{Reframing populist politics as democratic innovation}

Democratic innovations refer to the creation of spaces somewhere between deliberative democratic practices such as citizen juries, mini-publics and more direct, participatory, democratic procedures such as participatory budgeting (Elstub and Escobar, 2017). What is characteristic of democratic innovations is that they are designed to address the perceived limitations of the failings of representative democracy and, in this sense, are policy measures 'from above' which seek to legitimate and shape new forms of democratic life by renovating or reforming what exists already. On the other hand, populist politics 'from below' seeks to radically transform the kinds of political inequality which liberal democracy is based on and which it reinforces. Populist politics has the advantage of working in the idiom and culture of socially excluded groups in order to provide a voice and channel for addressing the anger and resentment which social and political inequality produces and sustains. Democratic innovation, in this sense, includes new and inclusive structures of participation 'from below', along with the generation of a culture and idiom of active political engagement rooted in lived experience.

In the context of the referendum, this culture of political participation loosened the vicelike grip of formal politics on political debate. It generated more inclusive and open spaces for participation in grassroots movements, aided by social media, which motivated widespread political debate in diverse spaces, in the home and in friendship networks. A consequence of these democratic innovations was that there were many different referendum debates, encompassing a range of social interests and a spectrum of ideological

3 http://www.womenforindependence.org

4 http://www.womensequality.org.uk/scotland_2016

5 https://safi4yes.wordpress.com

6 http://www.pinknews.co.uk/2014/09/01/scottish-independence-yes-lgbt-campaign-releases-rainbow-paper-for -scottish-equality-issues/

7 http://www.allofusfirst.org 
views. These developments showed the potential of democratic innovations 'from below' to revitalise the demos and to revitalise formal politics.

\section{Impact on formal politics}

Populist politics has had repercussions on formal politics at least in terms of influencing engagement with political parties and political events. It had immediate impact on support for the Scottish National Party (SNP), which has been the main political beneficiary, with membership more than trebling. It is now the third largest political party in the UK, whereas the Scottish population is only one tenth of the country. Increases in membership have been claimed by all the political parties that supported independence, not simply the SNP. Moreover, polling evidence suggests around 25\% of 16-17 year olds have joined a political party, with a similar number being involved in political campaigning since the referendum (Black, 2015).

Another indicator of this linkage of horizontal politics in communities impacting on organized politics has been attendance at political events. The Annual Convention of the SNP in November 2014 attracted a remarkable 12,000 members, and on the same weekend in Glasgow, 3,000 participants attended the Radical Independence Campaign's Annual Conference. The opposite trend seems to be occurring in the main Scottish political party supporting the union position - membership of the Scottish Labour Party is in deep decline. In the General Election in May 2015, the SNP achieved phenomenal success whereas the Scottish Labour Party and the Scottish Liberal Democrats haemorrhaged support and were almost wiped off the political landscape. The three political parties behind the pro-union campaign were only able to elect one MP each. In addition, the average turnout in Scotland was particularly high at $71.1 \%$ (the UK average being $66.1 \%$ ), rising to over $80 \%$ in two constituencies where the SNP gained seats (BBC.co.uk Election 2015).

In summary, the referendum led to a widening and deepening of politicisation in Scottish communities through both formal political processes but probably more so through the emergence of a deliberative and participatory form of populist politics. These political forces were also productive of various types of initiatives which enabled people to learn, discuss and argue the merits of a variety of issues and not merely those issues which dominated the agenda of the official campaigns. A pluralistic political culture which had vibrancy and popular energy emerged that filled the 'empty signifier' of independence with radical demands for addressing social and political inequality. We can now turn to see how adult education reacted to this new context.

\section{THE RESPONSE OF ADULT EDUCATION}

Education for democracy and social justice are always a product of wider social and political changes which create the motivation and spaces for reflection, study and social action. In the previous section we have seen how this need was met mainly through a 
myriad of different local groups, campaigns and movements. In general, however, educational provision up and down the country was slow to respond - if they responded at all.

\section{Voter registration}

Providing information on voter registration was regarded as the least sensitive political activity and therefore the most widespread in schools and communities across Scotland. The inclusion of 16 and 17 year olds in the vote placed an onus on schools to provide such information. At the same time, registration information was one issue that educators felt most comfortable with in that it appeared more procedural rather than responding to substantive policy and constitutional differences that divided the pro-union and independent camps.

However, the issue of registration was not merely procedural. Scotland had been the testing ground for the UK government's poll tax in the early 1990s, which because of its blatant unfairness, was vigorously resisted in Scottish communities and this eventually led to the downfall of Prime Minister Margaret Thatcher. Many people resisted the poll tax by going missing from the electoral register, and prior to the referendum, over a million adults were unaccounted for (Sullivan, 2014). These missing people had to weigh up the risk of becoming visible against their eligibility to vote. In the end $96 \%$ of the electorate was registered, which is a testimony to the fact that people understood how and why the vote was important.

\section{Political education}

There were also inspiring examples of educational activity. Learning to access political procedures was relevant to groups who had little or no previous experience of voting, of dealing with the paperwork of registering, and in making the connections between different political arguments as well as the difficult business of assessing claims and counter-claims. Participatory public spaces which enabled informed debate and 'safe' opportunities to listen to alternative points of view was important. These spaces for public engagement outside official channels can widen awareness and provide the chance to directly participate in debate and learn in more meaningful terms through contact with peers. If adult education is to foster critical intelligence, it needs to enable people to move beyond the limitations of personal experience.

Courses of study in history, culture, nationalism and political issues are instances of more formal adult education learning opportunities which provided spaces for in-depth examination of contentious claims. These were, of course, limited in terms of spread and the number of people involved but they were indicative of ways in which adult education can contribute to political analysis. A MOOC (Mass Open Online Course) on the Scottish Referendum, provided by the University of Edinburgh Centre for Constitutional Change, brought together critical insights from leading intellectuals nationally and internationally with opportunities for public online participation. It had over 10,000 registered participants from within and outside Scotland. 


\section{Barriers to political education}

Censorship and self-censorship: One significant barrier was the local state's response which, in some cases, censored educational activity by discouraging its provision. Also self-censorship occurred amongst educators who believed they would find little support from their colleagues and limited their own potential engagement. Whilst adult and community educators do work on contentious issues (e.g. racism, sexism, etc.), the boundaries of confidence did not extend to politically controversial ones. Uncertainty and insecurity in dealing pedagogically with political complexities was a theme which emerged later as a reason why many educators felt uneasy with political education.

Bias, propaganda and education: Worry over appearing to be biased also held some practitioners back. Adult educators need to be able to make the distinction between education and propaganda and understand the relationship between the two. Whilst propaganda is commonly understood as deliberate distortion of a position, its original meaning is the systematic presentation of arguments for a particular case. In this sense it is not simply the opposite of education; it can be educative by opening up ideas, values and information which have been suppressed by opposing groups. Political hustings, which compare the propaganda of different positions, can be educative as assumptions are exposed, questioned, defended and challenged. The key difference between education and propaganda is that education involves acquiring the tools for critical engagement and is open-ended, rather than telling people what to think.

The claim that education is open-ended is not the same as saying it is neutral. As Paulo Freire (1972) states, "being neutral in a situation of inequality is merely to side with the powerful". All education involves taking a stance in relation to what values and beliefs are important and the kind of knowledge and skills necessary to sustain and nurture them. In periods when the dominant hegemony is accepted, such values, beliefs, knowledge and skills seem natural and commonsense. It is only when disruptions occur to the canopy of assumptions which form the dominant hegemony - the cracks which populism reflects that the prospects for social change are stepped up.

The 'human relations' element of contentious issues: Binary choices in referendums squeeze decisions into one or another preference, which may generate false polarities that can exacerbate conflicts between people, particularly when they disguise a spectrum of views. False polarities on public issues spill over into interpersonal conflicts. The human relations element of this is clearly important so that respectful debate is managed. There is, moreover, no simple way in which recourse to 'facts' or information can reduce the tensions in this process. Often the facts themselves are hotly contested by the different sides both in relation to the status and weighting of the 'evidence' or what, indeed, are the significant facts which need to be considered. What might be highly significant to one group may be irrelevant to the other. Thus educators need to have the skills and confidence to manage tensions and disputes within groups and harness the energy this generates for learning and action. 


\section{Reinvigorating learning for democracy}

During 2016 and 2017 the universities of Edinburgh, Glasgow and Dundee, working along with committed allies in the Workers' Educational Association, the state-sponsored agency Education Scotland and Learning Link Scotland (a national learners' agency) have been busy promoting the agenda of learning for democracy. Three national events have been resourcing and stimulating professional interest in this work. The first event was held in the Scottish Parliament in Edinburgh and focused on what learning for democracy means and examples of practice during the referendum. The second event in Glasgow addressed the theme of political inequality and drew on international experiences and policy developments to think through how to address it. The third event at the University of Dundee focused on the practical skills for organising and campaigning, for area-based work to promote democratic life and how the university can be a resource to support this work.

These national events have aimed to include a range of voices and experiences to reflect on politics and educational practice. By their very nature they provide a challenge to understanding the purpose of adult education and how educators might further the struggles for a democratic life. The response from practitioners has been overwhelmingly positive, with many keen to revitalise their work and to ally it with a socially progressive cause. One such example is Camina (http://carminaproject.weebly.com/), a new initiative by a small group of community education practitioners that responds to the need to connect and support critical education practice and practitioners in Scotland. More needs to be done... and will be done.

\section{CONCLUSION: RENEWING DEMOCRACY AND RENEWING ADULT EDUCATION}

The Scottish context is probably an easy one to make this argument for the case of populist politics as potentially progressive and democratic rather than nasty, racist or xenophobic. Whilst there were examples of bigoted identity politics and interpersonal conflicts, the types of hardcore racism which have been evident in some parts of Europe and the US, backed by political leaders, were not evident or were very marginal (the experience of Brexit was very different in this respect). The political frontiers drawn by the official campaigns avoided, in the main, the othering of specific groups. These deeply regressive political practices seek to turn populist responses into supporting authoritarian solutions.

Nevertheless, the Scottish case can provide a good example of populist politics in a socially progressive cause by illustrating the impetus for new forms of political learning and education, which adult education needs to engage with. The synergies between the two are mutually productive. Adult education in Scotland, and adult education globally, is at a crossroads of isolation from social struggles by being hitched to dominant policy agendas which have little to do with democracy, social justice, equality or freedom. Working in the 'nooks and crannies' of policy can be productive but austerity, 'learnification', or performativity measures, are making such spaces increasingly difficult to 
find. The only way out of this is to ensure adult education connects once more to its historical roots of being an ally for enhancing democratic life. In taking up this challenge, adult education has to go beyond the limits of liberal democratic versions of democracy by renewing the culture and practice of grassroots democracy. It is its value in these terms which needs to be resuscitated and argued for. As long as adult education is simply a handmaiden for some other end, such as the development of human capital, the more likely it is to disappear altogether or morph into something completely different. Adult education has to be involved in history if it is to save its own soul. Its historic role is in promoting an expansive and inclusive democracy which can contribute towards the revitalisation of the demos and this, in turn, can contribute to the revitalisation of adult education.

Acknowledgements: thanks to the two anonymous referees for their helpful insights and comments as well as encouragement.

\section{REFERENCES}

Biesta, G. (2006). What's the point of lifelong learning if lifelong learning has no point? European Educational Research Journal, 5 (3/4), 169-180.

Black, A. (2015). Referendum inspires young activists. BBC News Scotland Politics, $16^{\text {th }}$ January. Retrieved from http://www.bbc.co.uk/news/uk-scotland-scotland-politics-30837608.

Clarke, J. and Newman, J. (2012). The Alchemy of Austerity. Critical Social Policy, 32(3), 299-319.

Coffield, F. (1999). Breaking the consensus: lifelong learning as social control. British Educational Research Journal, 25(4), 479-499.

Crowther, J. (2004). In and against lifelong learning: flexibility and the corrosion of character. International Journal of Lifelong Education, 23 (2), 125-136.

Crowther, J., Martin, I. and Shaw, M. (2007). Rescuing community education in Scotland from the smothering embrace of partnership. In R. Mark, R. Jay, B. McCabe and R. Moreland (Eds.), Researching Adult Learning: Communities and Partnerships in the Local and Global Context (pp. 109-116). Belfast: QUB.

Crouch, C. (2004). Post-Democracy. Cambridge: Polity Press.

Curtice, J. (2014). Messages from the voters: The 2014 local and European elections. IPPR Progressive Review, 21(1), pp. 77-81.

Elstub, S. and Escobar, O. (2017). A typology of democratic innovations. Paper presented for the Political Studies Association's Annual Conference, 10-12 ${ }^{\text {th }}$ April, 2017, Glasgow.

Fraser, N. (2005). Reframing justice in a globalizing world. New Left Review, 36 (Nov-Dec), 69-88.

Fraser, G. (2012). Community development and the politics of local government. Concept, 3 (3) Winter, $1-7$.

Freire, P. (1972). The Pedagogy of the Oppressed. London: Penguin.

Gramsci, A. (1971). Prison Notebooks. London: Lawrence Wishart.

Hindess, B. (2016). Against (the concept of) populism. Retrieved from https://www.opendemocracy.net/ barry-hindess/against-concept-of-populism.

Jasper, J. M. (1997). The Art of Moral Protest. Chicago: University of Chicago Press.

Laclau, E. (2005). On Populist Reason. London: Verso.

Lawrence, M. (2014). Political Inequality. London: Institute for Public Policy Research. 
Martin, I. (2003). Adult Education, lifelong learning and citizenship: some ifs and buts. International Journal of Lifelong Education, 22(6), 566-579.

McGregor, C. and Crowther, J. (2016). The transition movement as politics and pedagogy in communities. International Journal of Community Development, 53(1), 8-24.

Mishra, P. (2016). Welcome to the Age of Anger. The Guardian, $8^{\text {th }}$ December.

Mouffe, C. (2014). Populism is a necessity. Retrieved from http://www.theeuropean-magazine.com/ chantal-mouffe--4/8420-why-the-euneedspopulism.

Mouffe, C. (2016). The populist moment. Retrieved from opendemocracy.net/democraciabierta/ Chantal-mouffe/populist-moment.

Sennett, R. and Cobb, J. (1972). The Hidden Injuries of Class. London: Cambridge University Press.

Sullivan, W. (2014). The Missing Scotland. Edinburgh: Luath Press.

White, J. (2017). Brexit, populism and the promise of agency. Retrieved from https://www.opendemocracy.net/can-europe-make-it/jonathan-white/brexit-populism-and-promise-of-agency. 